\title{
Effect of the Quality of Infused Energy on Substrate Utilization in the Newborn Receiving Total Parenteral Nutrition
}

\author{
J. SALAS-SAlVADÓ, J. MOLINA, J. FIGUERAS, J. MASSÓ, C. MARTÍ-HENNEBERG. AND \\ R. JIMENEZ
}

Research Unit on Human Nutrition and Growth, Pediatrics, VII Division, University of Barcelona, Reus, Spain
[J.S.-S., J.Ma., C.M.-H.J; and the Department of Pediatric's and Pharmacy, Hospital Clinic, University of Barcelona, Barcelona, Spain [J.Mo., R.J.]

\begin{abstract}
Newborn infants $(n=26)$, subdivided into three groups in which only the nonprotein energy was manipulated, were studied during continuously administered total parenteral nutrition. Nonprotein energy intake was provided as a glucose/fat mixture, and fat energy represented $18 \%$ (group $\mathrm{A}$ ), $29 \%$ (group B), and $40 \%$ (group C). Energy expenditure and substrate utilization were measured by indirect calorimetry during a 6-h period. Other analyses included 24-h urinary nitrogen excretion, glycemia, and lipid profile. The results showed that glucose oxidation increased with increasing total glucose intake ( $p$ $<0.05$ ). Net fat oxidation was observed in all groups and increased with increasing percentage of energy infused as fat. The maximal oxidative glucose disposal rate observed was in group A $(11.2 \mathrm{~g} / \mathrm{kg} / \mathrm{d})$. Maximal fat oxidation observed was in group $C(2 \mathrm{~g} / \mathrm{kg} / \mathrm{d})$, in which energy delivered by fat represented $40 \%$. This group was more energy efficient than the others. Oxygen consumption was not affected by modification of the source of energy, but carbon dioxide production was higher in group $A(p<$ $0.05)$, as was the nonprotein respiratory quotient $(p<$ 0.05). Despite differences in carbon dioxide production, arterial capillary $\mathrm{PCO}_{2}$ was not affected and, together with the higher $(p<0.05)$ minute ventilation, suggests that adequate pulmonary compensation occurred during the low-fat regimen. Arterial capillary $\mathrm{PO}_{2}$ was lower during the high-fat regimen $(p<0.05)$. Protein oxidation was greater in group $A(1.14 \pm 0.32 \mathrm{~g} / \mathrm{kg} / \mathrm{d})$ than in group $B$ $(0.70 \pm 0.21 \mathrm{~g} / \mathrm{kg} / \mathrm{d})$ or group $C(0.78 \pm 0.28 \mathrm{~g} / \mathrm{kg} / \mathrm{d})$. These data suggest that total parenteral nutrition regimens containing between 29 and $40 \%$ of calories as fat emulsion result in enhanced protein retention. (Pediatr Res 33: 112 117, 1993)
\end{abstract}

\section{Abbreviations}

TPN, total parenteral nutrition

NPRQ, nonprotein respiratory quotient

EE, energy expenditure

$\mathrm{PcO}_{2}$, arterial capillary partial pressure of oxygen

$\mathrm{PcCO}_{2}$, arterial capillary partial pressure of carbon dioxide

$\mathrm{Vo}_{2}$, oxygen consumption

$\mathrm{VCO}_{2}$, carbon dioxide production

Received December 13, 1991: accepted September 14, 1992

Correspondence: J. Salas-Salvadó, Research Unit on Human Nutrition and Growth, VII Division. University of Barcelona. c/Sant Llorenç 21, 43201 Reus, Spain.

Supported in part by the European Society of Parenteral and Enteral Nutrition and the ORDESA. NUTREXPA Society.
The major goals of TPN are to provide adequate nutrition to maintain a body composition similar to that of the orally fed patient while causing the least physiologic and metabolic disturbance. Adverse effects of glucose-based TPN have been reported in adults and children (1-3).

Controversy exists as to which source of energy best influences energy storage and fat deposition. When glucose loads exceed energy maintenance requirements, lipogenesis from glucose has been observed in newborn infants (4), and the increased energy cost of this process was implicated in the lower fat deposition in infants receiving high-glucose compared with high-fat regimens (5). Discrepancies exist when no net lipogenesis from glucose is observed.

Substitution of part of glucose-derived calories with i.v. fat could reduce the undesirable effects and may improve nitrogen balance (6). The positive relationship between the amount of energy infused and nitrogen retention has been investigated in adults and infants $(7,8)$. However, controversy persists as to the precise role of the caloric source (glucose or fat) in preserving the best nitrogen balance. The "nitrogen-sparing" effect of fat may be explained in adults (9), during sepsis or trauma, by the increased endogenous mobilization that provides two ATP per carbon atom more than from glucose (10). This extra energy could be used for new tissue synthesis. Other investigators suggest that nonprotein calories, given either as glucose alone or as a glucose-lipid mixture, also promoted equivalent nitrogen retention $(11,12)$ and/or protein synthesis (13) in catabolic states. The conflicting results of the studies can be related to differences in experimental design, type of the infant pathology/clinical condition, age of patients, level of infused energy, and glucose:fat ratio.

The aim of the present study was to evaluate the energy substrate utilization, gas exchange, and protein metabolism in newborn infants receiving three different isocaloric, isonitrogenous TPN solutions in which only the proportions of calories derived from fat and glucose were varied.

\section{SUBJECTS AND METHODS}

Subjects. Twenty-six newborn infants in whom TPN was clinically indicated were investigated during the 1st wk of TPN therapy. Six were small-for-gestational-age infants (14), with one. three, and two placed in groups A, B, and C, respectively. The rest were appropriate-for-gestational-age newborn infants. An unchanging clinical condition was a prerequisite for inclusion. and a 24 -h hemodynamic stabilization period preceded the study. The clinical and anthropometric characteristics are summarized in Table 1. As part of the patient group assignment, skinfold measurements were made by the same observer at the start of the study in a standard protocol using a Harpenden skinfold 
Table 1. Clinical characteristics of the study subjects*

\begin{tabular}{|c|c|c|c|c|c|c|c|c|c|c|c|}
\hline Group & Patient & Birth Wt $(\mathrm{g})$ & $\begin{array}{c}\text { Wt at study } \\
\text { (g) }\end{array}$ & $\begin{array}{c}\text { Gestational } \\
\text { age (wk) }\end{array}$ & $\begin{array}{c}\text { Age at } \\
\text { study (d) }\end{array}$ & Sex & $\begin{array}{l}\text { Height } \\
(\mathrm{cm})\end{array}$ & $\begin{array}{c}\text { Type of } \\
\text { birth }\end{array}$ & Medication & EEG† & Pathology \\
\hline \multirow[t]{7}{*}{ A } & 1 & 3990 & 3980 & 40 & 6 & M & 53 & Forceps & & Normal & HIE \\
\hline & 2 & 3540 & 3650 & 41 & 6 & $\mathrm{~F}$ & 53 & Forceps & Phenobarbital & II & HIE \\
\hline & 4 & 2660 & 2680 & 38 & 6 & $\mathbf{M}$ & 50.5 & Forceps & & Normal & HIE \\
\hline & 5 & 3420 & 3450 & 40 & 6 & $\mathrm{M}$ & 51 & Eutocic & & Normal & HIE \\
\hline & 6 & 4550 & 4350 & 40 & 7 & $\mathrm{M}$ & 55 & Cesarean & & Normal & HIE \\
\hline & 9 & 2260 & 2310 & 40 & 12 & $\mathrm{~F}$ & 47 & Podalic & Phenobarbital & II & NE \\
\hline & Mean \pm SD & $3272 \pm 780$ & $3221 \pm 735$ & $39.7 \pm 1.3$ & $6.8 \pm 1.9$ & & & & & & \\
\hline \multirow[t]{6}{*}{ B } & 1 & 2350 & 2300 & 40 & 7 & $\mathrm{~F}$ & 46 & Forceps & & Normal & HIE \\
\hline & 2 & 2250 & 2240 & 41 & 10 & M & 48 & Eutocic & Phenobarbital & Normal & $\mathrm{NE}$ \\
\hline & 3 & 2600 & 2580 & 39 & 8 & $\mathbf{M}$ & 48 & Cesarean & Phenobarbital & Normal & HIE \\
\hline & 4 & 2620 & 2290 & 35 & 6 & $\mathbf{M}$ & 49 & Cesarean & & I & HIE \\
\hline & 9 & 3210 & 3290 & 41 & 6 & $\mathrm{~F}$ & 49 & Cesarean & & Normal & HIE \\
\hline & Mean \pm SD & $2634 \pm 472$ & $2629 \pm 575$ & $39.0 \pm 2.7$ & $8.6 \pm 3.0$ & & & & & & \\
\hline \multirow[t]{9}{*}{$\mathrm{C}$} & 1 & 3200 & 3320 & 40 & 7 & $\mathrm{M}$ & 53 & Forceps & Phenobarbital & II & HIE \\
\hline & 2 & 3350 & 3160 & 39 & 6 & $\mathrm{~F}$ & 51 & Cesarean & Phenobarbital & I & HIE \\
\hline & 3 & 1880 & 2030 & 34 & 7 & $\mathrm{~F}$ & 42 & Cesarean & & Normal & $\mathrm{EA}$ \\
\hline & 4 & 2730 & 2800 & 37 & 7 & $\mathrm{M}$ & 50.5 & Forceps & & II & HIE \\
\hline & 5 & 2860 & 2710 & 42 & 8 & $\mathrm{~F}$ & 52.5 & Cesarean & & Normal & GS \\
\hline & 6 & 3400 & 3500 & 42 & 6 & $\mathrm{~F}$ & 49 & Forceps & & I & HIE \\
\hline & 7 & 3630 & 3580 & 40 & 10 & $\mathrm{M}$ & 52 & Cesarean & Phenobarbital & II & NE \\
\hline & 8 & 2020 & 2150 & 37 & 12 & $\mathrm{M}$ & 45 & Cesarean & Phenobarbital & II & HIE \\
\hline & Mean \pm SD & $2883 \pm 646$ & $2906 \pm 589$ & $38.9 \pm 2.7$ & $7.8 \pm 2.1$ & & & & & & \\
\hline
\end{tabular}

* There was no statistical difference between groups $A, B$, and $C$ in any of the above variables.

+ I, minimal alterations: II, moderated alterations (38).

$\ddagger$ HIE, hypoxic ischemic encephalopathy; NE, necrotizing enterocholitis; EA, esophageal atresia; GS, gastroschisis.

calliper (16). Measurements were made at four sites on the left side of the body: over the triceps and biceps muscles and at the subscapular and suprailiac areas. The Brook equation (17) was used to determine child body density from the sum of the skinfold thicknesses at the four sites. Percentage of fat body mass was derived from body density using the Siri equations; percentage body fat $=(4.95 /$ density $)-4.5(18)$. No infant had proven infection, jaundice, or chromosomal abnormality. No subject was in respiratory distress requiring supplementary oxygen. Moderate and severe hypoxic ischemic encephalopathy (19) infants were maintained on a 7-d period of TPN to prevent necrotizing enterocholitis (20). During the study, these patients were maintained on spontaneous ventilation and presented clinical and hemo-gas analysis normality $\left[\mathrm{PCO}_{2}\right.$ between 37 and $55 \mathrm{~mm} \mathrm{Hg}$ (4.93 and $7.33 \mathrm{kPa}), \mathrm{PcCO}_{2}$ between 32 and $48 \mathrm{~mm} \mathrm{Hg}(4.27$ and $6.40 \mathrm{kPa})]$. All individuals had normal renal function during the study. The protocol was approved by the hospital ethical committee, and fully informed, written consent was obtained from the subjects' parents.

Nutrition protocols and study design. The subjects were randomly allocated to the three treatment groups. TPN regimens. commenced on day 1 and progressively stabilized by $\mathrm{d} 5$ of the study (Fig. 1), differed only in the source of nonprotein calories (glucose and fat) while remaining isonitrogenous and isocaloric. Nonprotein energy intake was provided as a mixture of glucose and long-chain fatty acids. Energy provided by fat represented $18 \%, 29 \%$, and $40 \%$ in groups $A, B$, and C, respectively.

TPN was delivered in 20 patients through a peripheral catheter (Abbocath, Abbott. IL) and, in six patients, through a central catheter (Epicutaneo-Cava, Vygon, Aachen, Germany). Nonprotein energy intake was provided by a separate infusion of longchain fatty acids (Intralipid 20\%, Kabi Vitrum. Stockholm. Sweden) and glucose over $24 \mathrm{~h}$. Nitrogen intake was from crystalline $\mathrm{l}$-amino acid solution (Primène 10\%. CERNEP Synthelabo, Paris. France) and represented approximately $1 \mathrm{~g}$ of protein $/ 40 \mathrm{kcal}$ administered. The nutrient intakes were determined from the measured volume of infusion. All infusions provided (per kg body weight/d) $140 \mathrm{~mL}$ total fluids, $3.5 \mathrm{mmol}$ sodium, $2 \mathrm{mmol}$ potassium, $3.5 \mathrm{mmol}$ chloride. $1 \mathrm{mmol}$ calcium. $0.33 \mathrm{mmol}$ magnesium, $0.3 \mathrm{mmol}$ phosphorus, $300 \mu \mathrm{g}$ zinc, 40 $\mu \mathrm{g}$ copper, and a multivitamin preparation (Polivitaminico Rius. Hospital de Sant Pablo, Barcelona. España) given at $2.5 \mathrm{~mL} / \mathrm{d}$. Regimens were supplemented with L-carnitine $(10 \mathrm{mg} / \mathrm{kg}$ body wt/d) to avoid the adverse effects of any possible carnitine deficiency on fat oxidation measurements. Parenteral solutions were prepared in the hospital pharmacy department under aseptic conditions and were administered at a constant infusion rate over $24 \mathrm{~h}$.

Indirect calorimetry and gas exchange measurements. Feeding regimens were kept constant for at least $24 \mathrm{~h}$ before indirect calorimetry measurements were performed.

$\mathrm{VO}_{2}$ and $\mathrm{VCO}_{2}$ were continuously measured for $6 \mathrm{~h}$ by opencircuit indirect calorimetry using the ventilated hood 2900 System (SensorMedics Corp., Anaheim, CA) adapted for children (21). Briefly, this cart is a mobile instrument with $\mathrm{O}_{2}$ and $\mathrm{CO}_{2}$. sensors that uses the principle of open-circuit indirect calorimetry. Before each measurement, the system was systematically calibrated using purified $\mathrm{N}_{2} / \mathrm{O}_{2}, \mathrm{~N}_{2} / \mathrm{O}_{2} / \mathrm{CO}_{2}$ mixtures at precise. predetermined compositions. The whole system was periodically checked using nitrogen dilution tests $(22)$ and $R Q$ tests by ethanol combustion (23) to verify the sensitivity of $\mathrm{VO}_{2}$ and $\mathrm{RQ}$ measurements (21). The percentage error in the estimation of RQ by the ethanol combustion tests at flows of $5.0-5.5 \mathrm{~L} / \mathrm{min}$ and $5.5-$ $6.0 \mathrm{~L} / \mathrm{min}$ was $4.9 \% \pm 1.8(n=14$; coefficient of variation $<$ $2.8)$ and $4.4 \% \pm 1.6(n=17$ : coefficient of variation $<3.1)$ respectively. 


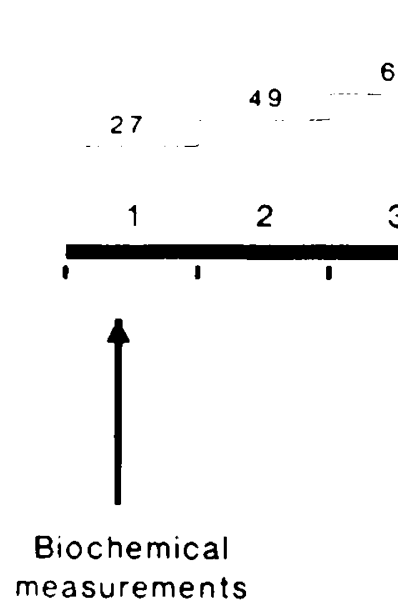

Fig. 1. Studỵ design.

Net substrate oxidation rates were calculated according to previously published methods (4, 24, 25). The 24-h urinary nitrogen excretion values were measured by the Kjeldahl method on the same day of the tests and were used to calculate NPRQ. In calculating oxidation rates, the following constants were used: $6.25 \mathrm{~g}$ of protein oxidized to produce $1 \mathrm{~g} \mathrm{~N}_{2}$ and $966 \mathrm{~mL} \mathrm{O}_{2}$ required to oxidize $1 \mathrm{~g}$ of protein to produce $774 \mathrm{~mL} \mathrm{CO} \mathrm{VO}_{2}$ was taken as $2019 \mathrm{~mL} / \mathrm{g}$ of fat (NPRQ $=0.696)$ and $746 \mathrm{~mL}$ of $\mathrm{O}_{2} / \mathrm{g}$ glucose $(\mathrm{NPRQ}=1)$. Fat deposition values were obtained from the fat infusion rate minus the net fat oxidation rate. EE was calculated from gaseous exchange using the NPRQ (4).

$\mathrm{PCO}_{2}$ and $\mathrm{PCCO}_{2}$ were measured on the same day of the calorimetric measurements. Alveolar ventilation (VA) was calculated from $\mathrm{V}\left(\mathrm{C}_{2}\right.$ and $\mathrm{PCCO}_{2}$ as $\mathrm{VA}=\mathrm{VCO}_{2} \times \phi \times \mathrm{PcCO}_{2}(\mathrm{~mL} / \mathrm{kg} / \mathrm{min}$, body temperature, pressure, saturated) where $\phi=863$; a constant that converts $\mathrm{VCO}_{2}$ to body temperature, pressure, saturated and the partial pressure to a fraction of $\mathrm{CO}_{2}$.

Biochemical tests. Venous blood samples were taken between 0900 and $1100 \mathrm{~h}$ before TPN commencement (d 1) and on the day of the calorimetric measurement (d 6). Plasma total cholesterol, triglyceride, phospholipid, and FFA were measured by CHOD-PAP enzymatic methods (Boehringer Mannheim, Germany). HDL cholesterol was measured in the plasma supernate after precipitation (with heparin manganese) of the lipoprotein containing apoprotein B. Apoproteins A-1 and B were measured using immunoturbidimetric methods (kit 67265 and D-249, Orion, Espoo, Finland). All lipoprotein analyses were conducted in the Cobas Mira automated centrifugal analyzer (Roche, Basel, Switzerland).

Statistical analysis. All results were expressed as mean $\pm \mathrm{SD}$. Nonparametric Mann-Whitney tests were used for comparisons between groups. Significance was designated as being greater than the $95 \%$ confidence limit. All descriptive and analytic statistics were performed using the spss/pc package (SPSS Inc., Chicago, IL).

\section{RESULTS}

There were no significant differences in birth weight, gestational age, weight, height, and age between the groups at the start of the study (Table 1). Percentage of fat body mass was $12.0 \pm$ 3.7.8.6 \pm 4.2 and $11.8 \pm 4.6$ in group $A$. B, and C, respectively, at the start of the study.

Growth rate, measured over a 3-d period, was $8.4 \pm 7.9 \mathrm{~g} / \mathrm{kg} /$ d. $8.3 \pm 8.4 \mathrm{~g} / \mathrm{kg} / \mathrm{d}$, and $13.3 \pm 11.2 \mathrm{~g} / \mathrm{kg} / \mathrm{d}$ in groups $\mathrm{A}, \mathrm{B}$, and $C$, respectively, during the study.

None of the patients had glucosuria or ketonuria during the study. Table 2 summarizes the infant plasma glucose and lipid profile at the start and end of the study. There were no significant
97

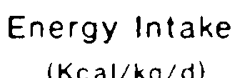

Day differences in plasma glucose, total cholesterol, HDL cholesterol. total FFA, and apoproteins A-1 and B between groups during the study. On the day of the calorimetric measurement, total plasma triglyceride concentrations were significantly different between groups $\mathrm{C}$ and $\mathrm{A}(p<0.05)$, as were the total plasma phospholipids between group $\mathrm{C}$ and groups $\mathrm{A}(p<0.01)$ and $\mathrm{B}$ $(p<0.05)$.

Table 3 summarizes the respiratory gas exchange values. There was no difference in $\mathrm{VO}_{2}$ values, whereas the $\mathrm{VCO}_{2}$ was significantly lower in group $\mathrm{C}$ than in groups $\mathrm{A}$ and $\mathrm{B}(9.2 \pm 1.0 \mathrm{~mL} /$ $\mathrm{kg} / \mathrm{min}$ versus $10.4 \pm 1.2$ and $10.4 \pm 1.3 \mathrm{~mL} / \mathrm{kg} / \mathrm{min} ; p<0.05)$. The NPRQ was $0.88 \pm 0.07$ in group $C$, which was significantly lower than in group $\mathrm{A}(0.96 \pm 0.06: p<0.05)$. but not significantly different from group B $(0.90 \pm 0.06 ; p=\mathrm{NS})$.

Despite the lower $\mathrm{VCO}_{2}$ during the high-fat regimen, the $\mathrm{PcCO} 2$ was not statistically different between groups, whereas $\mathrm{PcO}_{2}$ was significantly decreased, as was the alveolar minute ventilation in group $C$ relative to groups $A$ and $B$ (Table 3 ).

Table 4 summarizes the energy balance findings. Glucose oxidation increased with increasing glucose intake $(p<0.05)$. There were no significant differences in total glucose storage between groups. Net fat oxidation was observed in all groups and increased with the increasing percentage of energy infused as fat. Net fat oxidation increased from $0.83 \pm 1.04 \mathrm{~g} / \mathrm{kg} / \mathrm{d}$ in group A to $2.00 \pm 1.21 \mathrm{~g} / \mathrm{kg} / \mathrm{d}$ in group $C$ patients $(p<0.05)$. There were no significant differences in fat storage between groups. There were significant differences in protein oxidation between groups. Net protein oxidation was $1.14 \pm 0.32 \mathrm{~g} / \mathrm{kg} / \mathrm{d}$ in group $\mathrm{A}$, which was significantly higher than in group $\mathrm{B}(0.70 \pm 0.21 \mathrm{~g} / \mathrm{kg} / \mathrm{d}: p$ $<0.01)$ and group $\mathrm{C}(0.78 \pm 0.28 \mathrm{~g} / \mathrm{kg} / \mathrm{d} ; p<0.05)$. Protein retention was greatest in groups $\mathrm{B}$ and $\mathrm{C}$. EE was significantly lower and storage higher in group $C$ relative to group $B$ patients.

\section{DISCUSSION}

Carbohydrates are an important energy source in the course of TPN. However, high intakes of carbohydrates, usually administered as infusions of hypertonic glucose, may have certain disadvantages: 1 ) obligatory infusion by central venous catheters. 2) metabolic disturbances such as hyper- or hypoglycemia, 3) aggravation of respiratory acidosis resulting from increased $\mathrm{CO}_{2}$ production in patients with compromised pulmonary function. 4) fatty liver as a result of increased lipogenesis from glucose. and 5) rapid development of essential fatty acid deficiency in infants $(1,2,26)$. The administration of fat emulsions with lesser quantities of glucose can minimize many of these problems. However, there is little agreement on the amount and type of nonprotein calories required to prevent lipogenesis from glucose or to ensure adequate protein retention in the newborn infant. 
Table 2. Infant plasma glucose and lipid profile during study

\begin{tabular}{|c|c|c|c|}
\hline & Group A & Group B & Group C \\
\hline $\begin{array}{l}\text { TPN commencement }(\mathrm{d} 1) \\
\text { Plasma glucose }(\mathrm{mmol} / \mathrm{L}) \\
\text { Total cholesterol }(\mathrm{mmol} / \mathrm{L}) \\
\text { Triglycerides }(\mathrm{mmol} / \mathrm{L}) \\
\text { HDL cholesterol }(\mathrm{mmol} / \mathrm{L}) \\
\text { FFA }(\mathrm{mmol} / \mathrm{L}) \\
\text { Apo A-I }(\mathrm{mg} / \mathrm{dL}) \\
\text { Apo B }(\mathrm{mg} / \mathrm{dl}) \\
\text { Phospholipids }(\mathrm{mmol} / \mathrm{L})\end{array}$ & $\begin{array}{l}4.80 \pm 0.88 \\
2.37 \pm 1.22 \\
1.14 \pm 0.37 \\
0.81 \pm 0.29 \\
0.35 \pm 0.21 \\
66.2 \pm 9.3 \\
37.3 \pm 15.6 \\
2.21 \pm 0.61\end{array}$ & $\begin{array}{l}4.19 \pm 0.95 \\
2.37 \pm 1.44 \\
1.14 \pm 0.62 \\
0.89 \pm 0.36 \\
0.33 \pm 0.19 \\
58.4 \pm 14.8 \\
39.0 \pm 21.6 \\
2.24 \pm 1.10\end{array}$ & $\begin{array}{l}4.88 \pm 0.70 \\
2.05 \pm 0.57 \\
1.41 \pm 0.74 \\
0.65 \pm 0.28 \\
0.47 \pm 0.44 \\
59.9 \pm 9.0 \\
38.5 \pm 15.4 \\
2.23 \pm 0.66\end{array}$ \\
\hline $\begin{array}{l}\text { Calorimetric study (d } 6 \text { ) } \\
\text { Plasma glucose (mmol/L) } \\
\text { Total cholesterol (mmol/L) } \\
\text { Triglycerides (mmol/L) } \\
\text { HDL cholesterol (mmol/L) } \\
\text { FFA (mmol/L) } \\
\text { Apo A-l (mg/dL) } \\
\text { Apo B (mg/dl.) } \\
\text { Phospholipids (mmol/L) }\end{array}$ & $\begin{array}{l}5.22 \pm 0.76 \\
3.26 \pm 1.05 \\
0.93 \pm 0.51 \\
0.87 \pm 0.40 \\
0.17 \pm 0.15 \\
68.6 \pm 12.5 \\
45.7 \pm 10.7 \\
2.44 \pm 0.36\end{array}$ & $\begin{array}{l}5.16 \pm 1.28 \\
3.32 \pm 1.73 \\
1.03 \pm 0.30 \\
0.88 \pm 0.38 \\
0.23 \pm 0.30 \\
68.9 \pm 21.4 \\
40.9 \pm 17.7 \\
2.66 \pm 0.87\end{array}$ & $\begin{array}{l}5.15 \pm 0.67 \\
3.79 \pm 0.90 \\
1.53 \pm 0.74^{*} \\
0.73 \pm 0.23 \\
0.42 \pm 0.44 \\
68.3 \pm 12.5 \\
55.9 \pm 14.0 \\
3.13 \pm 0.37 \dagger \ddagger\end{array}$ \\
\hline
\end{tabular}

$* p<0.05$ is group A.

$\dagger p<0.01$ is group A.

$\ddagger p<0.05$ is group B.

Table 3. Respiratory gas exchange data

\begin{tabular}{lccc}
\hline & Group A & Group B & Group C \\
\hline $\mathrm{V}\left(\mathrm{O}_{2}(\mathrm{~mL} / \mathrm{kg} / \mathrm{min})\right.$ & $10.4 \pm 1.2$ & $10.4 \pm 1.3$ & $9.2 \pm 1.0^{*} \dagger$ \\
$\mathrm{NPRQ}$ & $0.96 \pm 0.06$ & $0.90 \pm 0.06$ & $0.88 \pm 0.07^{*}$ \\
$\mathrm{P}()_{2}(\mathrm{~mm} \mathrm{Hg}) \ddagger$ & $55.9 \pm 6.7$ & $52.3 \pm 3.7^{*}$ & $47.2 \pm 4.9 \S$ \\
$\mathrm{P}\left(\mathrm{O}_{2}(\mathrm{~mm} \mathrm{Hg}) \ddagger\right.$ & $42.5 \pm 4.7$ & $39.8 \pm 4.2$ & $42.3 \pm 3.3$ \\
Alveolar minute ventilation & $211 \pm 20$ & $225 \pm 22$ & $187 \pm 19^{*} \|$ \\
$\quad(\mathrm{mL} / \mathrm{kg} / \mathrm{min})$ & & & \\
\hline
\end{tabular}

$* p<0.05$ us group A.

$\dagger p<0.05$ is group $\mathrm{B}$.

$\ddagger$ SI unit conversion: $1 \mathrm{~mm} \mathrm{Hg}=0.1333 \mathrm{kPa}$.

$\$ p<0.01$ is group $\mathrm{A}$.

$\| p<0.01$ is group B.

Table 4. Energy balance and substrate intake, oxidation, and balance

\begin{tabular}{lccc} 
& Group A & Group B & Group C \\
\hline Energy $(\mathrm{kcal} / \mathrm{kg} / \mathrm{d})$ & & & \\
Intake & 96.1 & 97.4 & 98.7 \\
$\quad$ Expenditure & $54.5 \pm 7.3$ & $57.0 \pm 8.2$ & $50.9 \pm 4.9^{*}$ \\
$\quad$ Retained & $41.6 \pm 7.3$ & $40.3 \pm 8.2$ & $47.7 \pm 4.9^{*}$ \\
Glucose $(\mathrm{g} / \mathrm{kg} / \mathrm{d})$ & & & \\
Intake & 19.2 & 16.8 & 14.4 \\
Oxidation & $11.2 \pm 1.2$ & $9.71 \pm 2.63$ & $7.79 \pm 2.99 \dagger$ \\
Stored & $8.00 \pm 1.25$ & $7.09 \pm 2.63$ & $6.71 \pm 2.99$ \\
Fat $(\mathrm{g} / \mathrm{kg} / \mathrm{d})$ & & & \\
Intake & 1.5 & 2.50 & 3.50 \\
Oxidation & $0.83 \pm 1.04$ & $1.87 \pm 1.25$ & $2.00 \pm 1.21 \dagger$ \\
Stored & $0.67 \pm 1.04$ & $0.63 \pm 1.25$ & $1.50 \pm 1.21$ \\
Protein $(\mathrm{g} / \mathrm{kg} / \mathrm{d})$ & & & \\
Intake & 2.15 & 2.15 & 2.15 \\
Oxidation & $1.14 \pm 0.32$ & $0.70 \pm 0.21 \ddagger$ & $0.78 \pm 0.28 \dagger$ \\
Balance & $1.01 \pm 0.32$ & $1.45 \pm 0.21 \ddagger$ & $1.37 \pm 0.28 \dagger$ \\
\hline
\end{tabular}

${ }^{*} p<0.05$ is group B.

$\dagger p<0.05$ is group A.

$\ddagger p<0.01$ is group A.

Many studies have been designed to assess the effects of relatively large amounts of glucose (with or without fat) relative to low-glucose-content regimens on substrate utilization and protein metabolism. Few have been designed to compare the effects of the proportion of energy administered as carbohydrates and fats within a range normally applicable in clinical practice. In the present study, glucose-only TPN was not considered. because premature newborn infants have metabolic evidence of essential fatty acid deficiency as early as 5-8 d postpartum, and. hence, lipid infusion was considered an essential clinical requirement, in contrast to other studies $(5,13,27)$. The level and type of energy chosen was to sustain an adequate growth rate and an osmolarity suitable for peripheral infusion.

Oxidative glucose disposal rate increases in response to increasing glucose intake rate in the infant $(6)$, the newborn $(28,29)$, or the malnourished child ( 30 ), and there is a physiologic maximum to glucose oxidation (31). Various factors, such as the replacement of glucose by fat (32) and the composition of the infused fat, influence infant glucose oxidation. In our study, net fat oxidation was achieved in all groups of infants. The maximum fat oxidation capacity observed was approximately $2 \mathrm{~g} / \mathrm{kg} / \mathrm{d}$ at a fat infusion rate of $3.5 \mathrm{~g} / \mathrm{kg} / \mathrm{d}$. The maximum glucose infusion rate, $19.2 \mathrm{~g} / \mathrm{kg} / \mathrm{d}$, was in group $\mathrm{A}$, in which the elevated oxidative glucose disposal rate of $11.2 \pm 1.2 \mathrm{~g} / \mathrm{kg} / \mathrm{d}$ was also observed. However. in none of the groups of children did the maximal rate of oxidative glucose metabolism exceed the $17.9 \mathrm{~g} / \mathrm{kg} / \mathrm{d}$ observed by Bresson et al. (28) in children aged 2 to $17 \mathrm{mo}$, the $11 \pm 0.6$ $\mathrm{g} / \mathrm{kg} / \mathrm{d}$ observed by Sauer et al. (29) in their full-term and premature newborn infants, or the $19 \mathrm{~g} / \mathrm{kg} / \mathrm{d}$ of our previous studies in children recovering from malnutrition $(4,30)$.

In the present study, EE in groups $A$ and $B$ was significantly higher than in group $C$. This could be due to the high energy cost of the glucose processing, as previously observed by other investigators $(6,28-30)$. Conversely, a mixed-fuel regimen is more energy efficient, especially one in which $40 \%$ of calories, in excess of the EE, were provided by fat (group C). The higher fat infusion was accompanied by slight changes in the plasma lipid profile, which may indicate possible adverse effects of longterm Intralipid infusion.

In a study using a glucose-only regimen, a higher metabolic rate and lower fat storage was found (5). This was attributed to the high energy cost of de novo synthesis of fat from carbohydrate. Piedboeuf et al. (33) suggested that increased alveolar minute ventilation could explain the increased $E E$ resulting from the energy cost of breathing during a high-glucose/low-fat regimen. In our study, no group of children demonstrated a net lipid synthesis from glucose, although the alveolar minute ventilation 
was lower in the group receiving the greater quantity of energy in the form of lipids. As suggested by other investigators (27), an increase in protein turnover after the administration of a parenteral regime rich in glucose could also explain the increase in EE observed in our study. However, because we did not conduct protein turnover studies, we are unable to address this aspect.

The protein-sparing effect of glucose is well documented (7, 34). Although the nitrogen-sparing effect of fat has been observed in starving adults (9) during renutrition, differences of opinion still exist regarding the specific effects of energy sources (glucose and/or fat) on protein metabolism; in healthy adults, the most efficient nitrogen retention was achieved when carbohydrate was the major energy source (35), whereas in other studies of parenterally fed infants, fat infusion did $(6)$ or did not $(36,37)$ improve nitrogen balance. These glucose-based and glucose-lipid regimens, assessed in adults (12) and/or children undergoing TPN, resulted in equivalent nitrogen retentions. However, most of these studies had been conducted on limited numbers of polytraumatized subjects or patients with sepsis or in hypercatabolic states and. hence, the specific effects of these conditions on protein metabolism may have obscured the responses to the dietary modifications (38). Our children had neither sepsis nor infection, and only five had been studied 6-10 d after surgery. Overall, the results indicated that the addition of more calories as fat emulsion significantly reduced protein oxidation while significantly enhancing protein retention. The five postsurgery subjects, distributed among groups A, B, and C, did not materially affect the mean values of their respective groups. Substitution of glucose by fat resulted in a significant decrease in protein utilization for $\mathrm{EE}$ while markedly improving protein retention.

The study of Pineault et al. (36) suggested that, for an i.v. energy intake level sufficient to cover maintenance requirements, glucose and fat provided an equivalent nitrogen-sparing effect in nonsepsis full-term and premature infants. In their study, maximal glucose and fat infused were 17 and $3 \mathrm{~g} / \mathrm{kg} / \mathrm{d}$, respectively, in contrast to our present study maximums of 19.2 and $3.5 \mathrm{~g} /$ $\mathrm{kg} / \mathrm{d}$, respectively. Their patient selection (postsurgery recovery patients), together with smaller differences in TPN regimens with their study groups, could explain the discrepancy relative to our present findings regarding nitrogen retention. Conversely, the study by Bresson et al. (27), using indirect calorimetry and stable isotopes, provides supportive evidence to our present study that the use of a balanced glucose-lipid regimen, as opposed to glucose-alone regimen, results in decreased whole-body-protein turnover, protein catabolism, and amino acid oxidation rates.

In conclusion, our results demonstrate that substitution of glucose by fat emulsion significantly reduces protein oxidation while significantly enhancing protein retention. Hence, highglucose TPN regimens cannot be advocated, as they result in decreased protein retention and increased EE.

Acknowledgments. The authors thank Mercedes Heras for her expertise in the lipoprotein measurements and Dr. Peter R. Turner of SciMed for editorial advice and manuscript preparation.

\section{REFERENCES}

1. Stein TP. Mullen JL 1985 Hepatic fat accumulation in man with excess parenteral glucose. Nutr Res 5:1347-1351

2. Clouse RE. Alpers DH 1984 Energy sources for total parenteral nutrition patients: would sugar suffice? Gastroenterology 87:226-227

3. Ekman L, Wretlind A 1985 Utilization of parenteral energy sources. In: Garrow JS, Halliday D (eds) Substrate and Energy Metabolism. John Libbey, London, pp 222-231

4. Salas J, Dozio E, Goulet O, Marti-Henneberg C. Moukarzel E, Ricour C 1991 Energy expenditure and substrate utilization in the course of renutrition of malnourished children. JPEN 15:288-293

5. Van Aerde J, Sauer PJ, Pencharz P, Smith JM, Swyer PR 1989 Effect of replacing glucose with lipid on the energy metabolism of newborn infants. Clin Sci 76:581-588
6. Nose O. Tipton JR. Ament ME. Yabuuchi H 1987 Effect of the energy source on changes in energy expenditure, respiratory quotient, and nitrogen balance during total parenteral nutrition in children. Pediatr Res 21:538-541

7. Munro HN 1964 General aspects of the regulation of protein metabolism by diet and by hormones. In: Munro HN, Allison JB (eds) Mammalian Protein Metabolism. Academic Press, New York. pp 381-481

8. Zlotkin SH, Bryan MH. Anderson GH 1981 Intravenous nitrogen and energy intakes required to duplicate in utero nitrogen accretion in prematurely born human infants. J Pediatr 99:115-120

9. Blakburn GL, Flatt JP, Clowes GHA, O'Donnell TF, Hensle TE 1973 Proteinsparing therapy during periods of starvation with sepsis or trauma. Ann Surg 177:588-593

10. Weast RC 1970 Handbook of Chemistry and Physics. Chemical Rubber Company, Cleveland

11. Tulikoura I, Huikuri K 1981 Changes in nitrogen metabolism in catabolic patients given three different parenteral nutrition regimens. Acta Chir Scand 147:519-524

12. Jeejeebhoy KN, Anderson GH, Nakhooda AF, Greenberg GR, Sanderson I. Marliss EB 1976 Metabolic studies in total parenteral nutrition with lipid in man. J Clin Invest 57:125-136

13. Baker JP, Detsky AS, Stewart S, Whitwell J, Marliss EB, Jeejeebhoy KN 1984 Randomized trial of total parenteral nutrition in critically ill patients: metabolic effects of varying glucose-lipid ratios as the energy source. Gastroenterology $87: 53-59$

14. Usher R. McLean F 1969 Intrauterine growth of live-born Caucasian infants at sea level: standards obtained from measurements in 7 dimensions of infants born between 25 and 44 weeks of gestation. J Pediatr 74:901-910

15. Druyfus-Brisac C. Monod M 1975 The electroencephalogram of full-term newborns and premature infants. In: Lairy $\mathrm{G}$ (ed) Handbook of Electroencephalography and Clinical Neurophysiology. Elselvier, Amsterdam. pp 6-30

16. Sempe M. Pedron G, Roy-Pernot MP 1979 Auxologie Methodes et Sequences. Editions Theraplix. Paris, pp 138-162

17. Brook CGD 1971 Determination of body composition of children from skinfold measurements. Arch Dis Child 46:182-184

18. Siri WE 1961 Body composition from fluid spaces and density: analysis of methods. In: Brozek J, Henschel A (eds) Techniques for Measuring Body Composition. National Academy of Science. Washington. DC. pp 223-244

19. Levene MI 1985 The incidence and severity of post-asphyxial encephalopathy in full-term infants. Early Hum Dev 11:21-28

20. Bargunõ JM. Figueras J, Botet F, Jimenez J 1988 Factores etiopatogénicos de la enterocolitis necrotizante neonatal. Ann Esp Pediatr 29:31-36

21. Salas J, Moukarzel E. Dozio E. Goulet O. Ricour C 1990 Estimation of resting energy expenditure by simple lean body mass indicators in children on total parenteral nutrition. Am J Clin Nutr 51:958-962

22. Kappagoda CT, Linden RJ 1972 A critical assessment of an open circuit technique for measuring oxygen consumption. Cardiovasc Res 6:589-597

23. Lister G, Hoffman JIE. Rudolph AM 1974 Oxygen uptake in infants and children: a simple method for measurement. Pediatrics 53:656-662

24. Ferranini E 1988 The theoretical bases of indirect calorimetry: a review. Metabolism 37:287-301

25. Frayn KN 1983 Calculation of substrate oxidation rates in vivo from gaseous exchange. J Appl Physiol 55:628-634

26. Friedman $Z 1987$ Essential fatty acid requirements for term and preterm infants. In: Horisberger M, Bracco U (eds) Lipids in Modern Nutrition. Nestle Nutrition. Raven Press, New York, pp 79-82

27. Bresson JL, Bader B, Rocchiccioli F. Mariotti A. Ricour C. Sachs C. Rey J 1991 Protein-metabolism kinetics and energy-substrate utilization in infants fed parenteral solutions with different glucose-fat ratios. Am J Clin Nutr $54: 370-376$

28. Bresson JL, Narcy P, Putet G, Ricour C. Sachs C. Rey J 1989 Energy substrate utilization in infants receiving total parenteral nutrition with different glucose to fat ratios. Pediatr Res 25:645-648

29. Sauer PJJ, Van Aerde JEE, Pencharz PB. Smith JM. Swyer PR 1986 Glucose oxidation rates in newborn infants measured with indirect calorimetry and (U-13C) glucose. Clin Sci 70:587-593

30. Salas J. Girardet JP, De Potter S. Marti-Henneberg C. Goulet O. Ricour C 1991 Glucose versus glucose-fat mixture in the course of total parenteral nutrition: effects on substrate utilization and energy metabolism in malnourished children. Clin Nutr 10:272-278

31. DeFronzo RA, Jacot E, Jequier E, Maeder E, Wahren J, Felber JP 1981 The effect of insulin on the disposal of intravenous glucose. Diabetes 30:10001007

32. Sauer PJJ 1990 Carbohydrate metabolism in growing infants. In: Chapman TE, Berger R. Reijngoud DJ, Okken A (eds) Stable Isotopes in Pediatric Nutritional and Metabolic Research. Intercept, Hampshire. UK, pp 23-34 
33. Piedboeuf B. Chessex P. Hazan J. Pineault M. Lavoie JC 1941 Total parenteral nutrition in the newborn infant: energy substrates and respiratory gas exchange. J Pediatr 118:97-102

34. Gamble LJ 1951 Lane medical lectures: companionship of water and electrolites in the organization of body fluids, Vol 5. Stanford University Publications. University Series, Medical Sciences, Stanford, CA, pp 7!-75

35. Richardson DP. Wayler AH. Scrimshaw NS. Young VR 1979 Quantitative effect of an isoenergetic exchange of fat for carbohydrate on dietary protein utilization in healthy young men. Am J Clin Nutr 32:2217-2226

36. Pincialt M. Chessex P. Bisaillon S. Brisson G 1988 Total parenteral nutrition in the newborn: impact of the quality of infused energy on nitrogen metabolism. Am J Clin Nutr 47:298-304

37. Pencharı P. Beesley J. Sauer P. Van Aerole J. Canagarayar U, Renner J. McVey M. Wesson D, Swyer P 1989 Total-body protein turnover in parenterally fed neonates: effects of energy source studied by using $\left[{ }^{15} \mathrm{~N}\right] \mathrm{glycine}$ and $\left[1-{ }^{13} \mathrm{C}\right]$ leucine. Am J Clin Nutr 50:1395-1400

38. Clowes GHA, George BC, Villee CA. Saravis CA 1983 Muscle proteolysis induced by a circulating peptide in patients with sepsis or trauma. $\mathrm{N}$ Engl $\mathrm{J}$ Med 308:545-552

\section{Announcement}

In view of the appalling events that have occurred in Somalia in the past several months, there is a recognized need in Somalia for medical expertise at the most basic level of pediatric and nutritional care. Moreover. this need is likely to exist for months and even years beyond resolution of the political and social events presently taking place.

Accordingly, you are being asked to join in a volunteer effort to provide medical care to an entire generation of infants and children in Somalia. Due to the current civil unrest in that country, there is no intent to begin provision of such care until order is restored. However, to avoid undue delay at that time. we are asking now for the names of volunteers. By organizing now, it will be possible to mount a meaningful effort within days that might otherwise require months. Because there are thousands of deaths weekly in Somalia, by starting now we may be able to save many thousands of children who will undoubtedly die without us.

Because it is likely that the need for our services will extend beyond a 12-month period. volunteers for 1 to 4 months (or longer), as schedules permit, within the next 24-month period will be gratefully accepted.

For more information. please contact: Karl S. Roth, M.D., or Festus O. Adebonojo, M.D., Department of Pediatrics, Medical College of Virginia, Childrens Medical Center, Box 239, Richmond, VA 23298-0239. 